\title{
Evaluation of Anti-inflammatory and Antisickling Potentials of Archidium ohioense (Schimp. ex Mull) Extracts
}

\author{
${ }^{1}$ Akinpelu, Bolajoko Ayinke; ${ }^{2}$ Makinde, Amos Morakinyo; \\ ${ }^{3}$ Amujoyegbe,Olayinka Olajumoke $;^{2}$ Isa, Musibau Olalekan; \\ ${ }^{1}$ Onwobiko, Victor Chinemerem; ${ }^{2}$ Akinwotu, Akintunde Oluwadare; \\ ${ }^{2}$ Oladimeji,Ezekiel Seun; ${ }^{3}$ Agbedahunsi, ${ }^{3}$ JosephMorunfolu; \\ ${ }^{1}$ Oyedapo, Oluokun Oluboade. \\ ${ }^{I}$ Department of Biochemistry, Faculty of Science, Obafemi Awolowo University, Ile-Ife, Nigeria \\ ${ }^{2}$ Department of Botany, Faculty of Science, Obafemi Awolowo University, Ile-Ife, Nigeria \\ ${ }^{3}$ Drug Research and Production Unit, Faculty of Pharmacy, Obafemi Awolowo University, Ile-Ife, Nigeria
}

\begin{abstract}
The study investigated the possible anti-inflammatory and antisickling potential of a moss plant A. ohioense.The phytoconstituents of acetone, chloroform and ethylacetate extracts of the plant were analysed using standard methods. Membrane stabilizing, antisickling, xanthine oxidase and lipooxygenase inhibitory activities of the extracts of the plants on sickle and normal erythrocytes were conducted. Phytochemically, the ethylacetate, acetone and chloroform extracts of A. ohioense showed the presence of cardiac glycoside, flavonoids, saponin, steroid, alkaloids and triterpenes. The acetone and ethyl acetate extracts of the plant stabilized red blood cell membrane of normal and sickle erythrocytes at various concentrations except at 2.0 $\mathrm{mg} / \mathrm{ml}$ while the chloroform extract exhibits profound protective effect on both normal and sickle erythrocytes at highest concentration used $(2.0 \mathrm{mg} / \mathrm{ml})$.All the A. ohioense extracts showed mild anti-lipoxygenase and xanthine oxidase inhibitory activities. As the concentrations of the A. ohioense chloroform and acetone extracts increased, the percentage inhibition of sickling significantly increased and compared favorably with Parahydroxybenzoic acid. These two extracts also demonstrated significant $(p \leq 0.0001)$ dose dependent increase in antisickling reversal activity.
\end{abstract}

This study indicates that A. ohioense could be valuable source of anti-inflammatory and antisickling agents.

Keywords: Archidium ohioense, antiinflammatory, antisickling, erythrocytes.

\section{Introduction}

Sickle cell disease (SCD) or drepanocytosisis a genetic disorder, characterized by the presence of the he- moglobin S (HbS).SCD is as a consequence of a single point mutation at the sixth codon of the normal haemoglobin genewhere valine replaces glutamic acid at the beta globin chain [1]. HbS molecules polymerize under low oxygen tension, causing the formation of rigid and sickle erythrocytes. The deformity of the sickled red blood cells results in their shortened survival since they become vulnerable to lysis as penetrate the interstices of the splenic sinusoids and hence severe hemolytic anemia ensues with hemoglobin values ranging from 6 to $10 \mathrm{~g} / \mathrm{L}[2,3]$.

SCD has been associated with acute and chronic clinical manifestations such as vaso-occlusive episodes (VOE), painful crisis, hemolysis, impaired blood flow as a result of intravascular sickling in capillary and vessels, inflammation processes and high susceptibility to infection, acute chest syndrome etc [4]

Plants are often employed as medicines for the treatment of diseases because they are known to synthesize bioactive compounds. The management or treatment goals for sickle cell disease aim to relieve pain, prevent infections and manage complications [5]. Some medicinal plant extracts have been reported to inhibits /decreased polymerization of $\mathrm{HbS}$ molecules $[6,7]$ and have been established to serve as potential antisickling chemotherapeutic preparations $[8,9]$.

A. ohioense is a short and tiny perennialplant that growabout $2-20 \mathrm{~mm}$ high in clusters to form denseand short turfs. The colour ranges from green toyellow-green. A. ohioense stems are simple variable or often short and multi-branched by numerous innovations from axils of stem leaves or exterior perichaetial leaves. As the plant aged it become prostrate, fragile and often detached. [10]. This study is part of ongoing attempts to exploit the therapeutic potentials of a lower plant(A. ohioense) in treatment and management of inflammation and sickle cell disorder. 


\subsection{Collection of Plant}

\section{Materials and Methods}

Fresh plants ofA. ohioense was collected on a rock surface at road 8, Obafemi Awolowo University Senior Staff Quarters, Ile-Ife, Nigeria. The plant was identified and authenticated by Dr. A.M. Makinde of the Department of Botany, Obafemi Awolowo University, Ile-Ife, Nigeria.

\subsection{Preparation of Plant Extracts}

The fresh plant was harvested, rinsed in water and air dried at room temperature. The plant was milled using manual grinding machine and soaked separately with ethyl acetate, acetone and chloroform. The solution was separately decanted and filtered after $72 \mathrm{~h}$. The residues were re-soaked in each of the solvents for another $72 \mathrm{~h}$. The filtrate of each solvent was pooled and evaporated to dryness under reduced pressure at $35^{\circ} \mathrm{C}$ on rotatory evaporator.

\subsection{Phytochemical Screening}

The ethanolic extract was phytochemically screened for the presence of secondary metabolitesas described by Evans (2002) [12] and Sofowora (2006)[13]

\subsection{In vitro Anti-inflammatory Activities}

\subsubsection{Membrane Stabilization}

\subsubsection{Preparation of reference drugs}

Ibuprofen (a non-steroidal anti-inflammatory drug) tablet $(500 \mathrm{mg}$ ), a reference drug for membrane stabilizing activity, was purchased from Campus Pharmacy of Obafemi Awolowo University, Ile-Ife, Nigeria. The tablets were ground to powder and dissolved separately in normal saline to obtain concentrations of $1.0 \mathrm{mg} / \mathrm{ml}$ and $2.0 \mathrm{mg} / \mathrm{ml}$ respectively.

\subsubsection{Collection of Blood Samples}

Fresh normal and sickle blood samples $(5 \mathrm{ml})$ each were collected by venipuncture into heparinized bottles at Obafemi Awolowo University Teaching Hospital Complex (OAUTHC), Ile-Ife.The sickle blood samples were collected from confirmed sickle cell anaemia patients who were in a steady state and attending the routine clinic. Ethical clearance was obtained from the Ethical Committee of the Obafemi Awolowo University Teaching Hospital Complex, Ile-Ife, Nigeria.

\subsubsection{Preparation of red blood cells}

Red blood cells were prepared as described by Oyedapo et al., (2010) [ 14]. Freshly collected human normal and sickle blood samples were poured separately into clean dried centrifuge tubes and centrifuged at $3000 \mathrm{rpm}$ for 15 minutes. The supernatant was carefully removed with the aid of dropping pipettes and residuewas re-suspended in fresh isosaline, mixed carefully and gently to prevent lyses of red blood cells. The process of centrifugation was repeated until a clear supernatant was obtained. To $2 \mathrm{ml}$ of the packed cell was added $98 \mathrm{ml}$ of isosaline to make a $2 \%(\mathrm{v} / \mathrm{v})$ red blood cells.

\subsubsection{Membrane stabilizing assay}

The membrane stabilizing activity assay method was based on the procedure described by Oyedapo $e t$ al. (2004)[15]. The assay mixture was made up of hyposaline (2 ml), $0.1 \mathrm{M}$ phosphate buffer, $\mathrm{pH} 7.4(1.0 \mathrm{ml})$, varying volumes of extract $(0.0-1.0 \mathrm{ml})$ at a concentration of $2.5 \mathrm{mg} / \mathrm{ml}$ and $2 \%(\mathrm{v} / \mathrm{v}, 0.5 \mathrm{ml})$ erythrocyte suspension to a total volume of $4.5 \mathrm{ml}$. The control was prepared as above without the drug while the drug control $(4.5 \mathrm{ml})$ lacked fixed red blood cell.The reaction mixtures were incubated at $56^{\circ} \mathrm{C}$ for $30 \mathrm{~min}$. The supernatants were collected into test tubes and the absorbance of the released haemoglobin was read at $560 \mathrm{~nm}$ against reagent blank.The percentage membrane stability was estimated using the expression:

Percentage Membrane Stability $=100-\{$ Abs test drug - Abs drug control $\}$ x 100

\{Abs of blood control\}

Where the blood control represented $100 \%$ lyses. The values represent the average of triplicates \pm SEM

\subsubsection{Assay of Anti-Lipoxygenase Activity}

Anti-lipoxygenase activity of the extracts with linoloeic acid as substrate was measured as described by Malterud and Rydland (2000)[16]. The assay mixture consisted of $150 \mu \mathrm{l}$ phosphate borate (1/15 M, pH 7.5), extract solution $(50 \mu \mathrm{l}), 50 \mu \mathrm{l}$ enzyme solution $(0.28 \mathrm{U} / \mathrm{ml}$ in phosphate borate). The reaction was initiated by the addition of $250 \mu \mathrm{l}$ of the substrate solution $\left(0.15 \mathrm{mM}\right.$ in distilled $\left.\mathrm{H}_{2} \mathrm{O}\right)$. Enzymatic kinetic was recorded at 
$234 \mathrm{~nm}$ for $2 \mathrm{~min}$ at $30 \mathrm{~s}$ intervals. All the assay was performed in triplicate and lipoxygenase activity was calculated using the expression shown below. One Unit (U)will convert $1.0 \mu$ mole of xanthine to uric acid per seconds at $\mathrm{pH} 7.5$ at $25^{\circ} \mathrm{C}$.

Volume activity $=\frac{\Delta O D / \sec \times t v \times d f}{12.5 \times l \times s v}$

$\mathrm{tv}=$ Total volume $(0.5 \mathrm{ml}) \quad \mathrm{sv}=$ Sample volume

12.5= Millimolar extinction coefficient of uric acid under the assay condition $\left(\mathrm{n}^{-1} \mathrm{~cm}^{-1}\right)$

$1=$ Light path length $\mathrm{df}=$ Dilution factor

$\triangle O D /$ sec $=$ Change in absorbance per seconds

\subsubsection{Xanthine Oxidase Inhibitory Assay}

Xanthine oxidase inhibitory activity of the extracts with xanthine as substrate was as described by Ferraz Feliah et al. (2006) [17].Theextracts were separately dissolved in phosphate buffer-MeOH (1\%) and assayed for xanthine oxidase inhibitory activity at final concentration of $50 \mu \mathrm{g} / \mathrm{ml}$. The assay mixture consisted of $150 \mu \mathrm{l}$ phosphate buffer $(1 / 15 \mathrm{M}, \mathrm{pH} 7.5)$, extract solution $(50 \mu \mathrm{l})$ and $50 \mu 1$ enzyme solution $(0.28 \mathrm{U} / \mathrm{ml}$ in phosphate buffer.) The reaction was initiated by the addition of $250 \mu$ l of the substrate solution. Enzymatic kinetic was recorded at $295 \mathrm{~nm}$ for 2 min at 30s intervals. All the assay was performed in triplicate. Xanthine oxidase inhibitory activity was calculated as volume activity using the equation below. One Unit $\mathrm{U}$ will convert $1.0 \mu$ mole of xanthine to uric acid per second at $\mathrm{pH} 7.5$ at $25^{\circ} \mathrm{C}$.

Volume activity $=\frac{\Delta O D / \sec \times t v \times d f}{12.5 \times l \times s v}$

$\mathrm{tv}=$ Total volume $(0.5 \mathrm{ml}) \quad \mathrm{sv}=$ Sample volume

12.5= Millimolar extinction coefficient of uric acid under the assay condition $\left(\mathrm{n}^{-1} \mathrm{~cm}^{-1}\right)$

$1=$ Light path length $\mathrm{df}=$ Dilution factor

$\triangle O D /$ sec $=$ Change in absorbance per seconds

\subsection{Antisickling Assay}

\subsubsection{Inhibitory assay}

The evaluation of extractsA. ohioensefor antisickling activities was carried out using procedures that was based on the methods of Egunyomi et al.(2009)and Sofowora et al. (1979) [18, 19].The washed erythrocytes $(0.2 \mathrm{ml})$, phosphate buffered saline $(0.2 \mathrm{ml})$ and the test extract $(0.2 \mathrm{ml})$ were mixed together in a test tube. The mixture was overlaid with $1 \mathrm{ml}$ of liquid paraffin. The mixture was then incubated in a thermostated water bath at $37^{\circ} \mathrm{C}$ for $4 \mathrm{hr}$. Freshly prepared $2 \%(\mathrm{w} / \mathrm{v})$ sodium metabisulphite solution $(0.6 \mathrm{ml})$ was carefully added to the mixture under the paraffin, mixed gently by rolling the test tube between the two palms and incubated for additional $11 / 2 \mathrm{~h}$ at $37^{\circ} \mathrm{C}$ in a water bath. The liquid paraffin was carefully removed using a Pasteur pipette and the cell was fixed with $3 \mathrm{ml}$ of $5 \% \mathrm{w} / \mathrm{v}$ buffered formalin solution. The positive control was treated described above except parahydroxybenzoic acid (PHBA) was added instead of extract while the negative control lacked extract but normal saline. Each test was performed in triplicate. A drop of each reaction mixture was smeared on a microscope slide and viewed under high powered magnification (x 100) under the oil immersion. Cells were counted on five fields on each slide the numbers of sickled and unsickled cells were counted to determine the total number of cells. The percentage mean sickling as well as the percentage inhibition activity for each extract were estimated using the expression below:

$\%$ Mean Sickling $=\quad \underline{\text { Mean sickled cells } \times 100}$

Mean total cells

$\%$ Inhibition activity $=\underline{\text { Control }-\% \text { Mean sickled }} \times 100$

Control

\subsubsection{Reversal Antisickling Assay}

The antisickling activity of chloroform and acetone of $A$. ohioense extracts was carried out using modified methods of Egunyomi et al. (2009) and Sofowora et al. (1979) [18, 19]. Mixture of the washed erythrocytes $(0.2 \mathrm{ml})$ and $0.2 \mathrm{ml}$ phosphate buffered saline in a test tube was carefully overlaid with $1 \mathrm{ml}$ liquid paraffin and $0.6 \mathrm{ml}$ of $2 \%(\mathrm{w} / \mathrm{v})$ sodium metabisulphite was carefully introduced under the liquid paraffin. The mixture was then incubated at $37^{\circ} \mathrm{C}$ for ninety minutes. At the end of the incubation period, $0.2 \mathrm{ml}$ of the extract was carefully added under the liquid paraffin and was further incubated at $37^{\circ} \mathrm{C}$ for additional $6 \mathrm{hr}$. The liquid paraffin layer was removed with a Pasteur pipette and the cells were fixed with $3 \mathrm{ml}$ of $5 \%$ (w/v) buffered formalin solution, which was carefully mixed by rolling the test tube between the two palms. The positive 
control also involved all the procedure described bove except that PHBA was added instead of extract while the negative control was normal saline. A drop of each reaction mixture was smeared on a microscope slide and viewed under high powered magnification (x 100) under the oil immersion. Cells were counted on five fields on each slide, the number of sickled and unsickled cell were counted to determine the total number of cells. The percentage mean sickling as well as the percentage reversal activity for each extract was estimated using the expression below:

$\%$ Reversal activity $=\underline{\text { Control- } \% \text { Mean sickledx }} 100$

Control

Total number of cells counted $=$ No of sickled + No of Unsickled cells

\subsection{Statistical Analysis}

Values are expressed as mean \pm SEM of 3 consistent readings. The statistical significance differences were analyzed using Student-- Newman- Keuls Multiple Comparison test and analysis of variance. Values of $\mathrm{p}<$ 0.0001 were considered to be extremely significant.

\section{Results}

Table 1. Phytochemical Constituents in the Ethylacetate, Acetone and Chloroform Extracts of Archidium Ohioense

\begin{tabular}{|l|l|l|l|}
\hline & Ethylacetate Extract & Acetone Extract & Chloroform Extract \\
\hline Alkaloids & + & + & - \\
\hline Flavonoids & + & + & + \\
\hline Saponins & + & + & + \\
\hline Tannins & + & - & - \\
\hline Anthaquinones & - & - & - \\
\hline Cardiac glycosides & + & + & + \\
\hline Phlobatanins & - & + & - \\
\hline Steroids & + & + & + \\
\hline Triterpenes & + & + \\
\hline Xanthoproteins & + & - & - \\
\hline
\end{tabular}

+ Present

- Absent
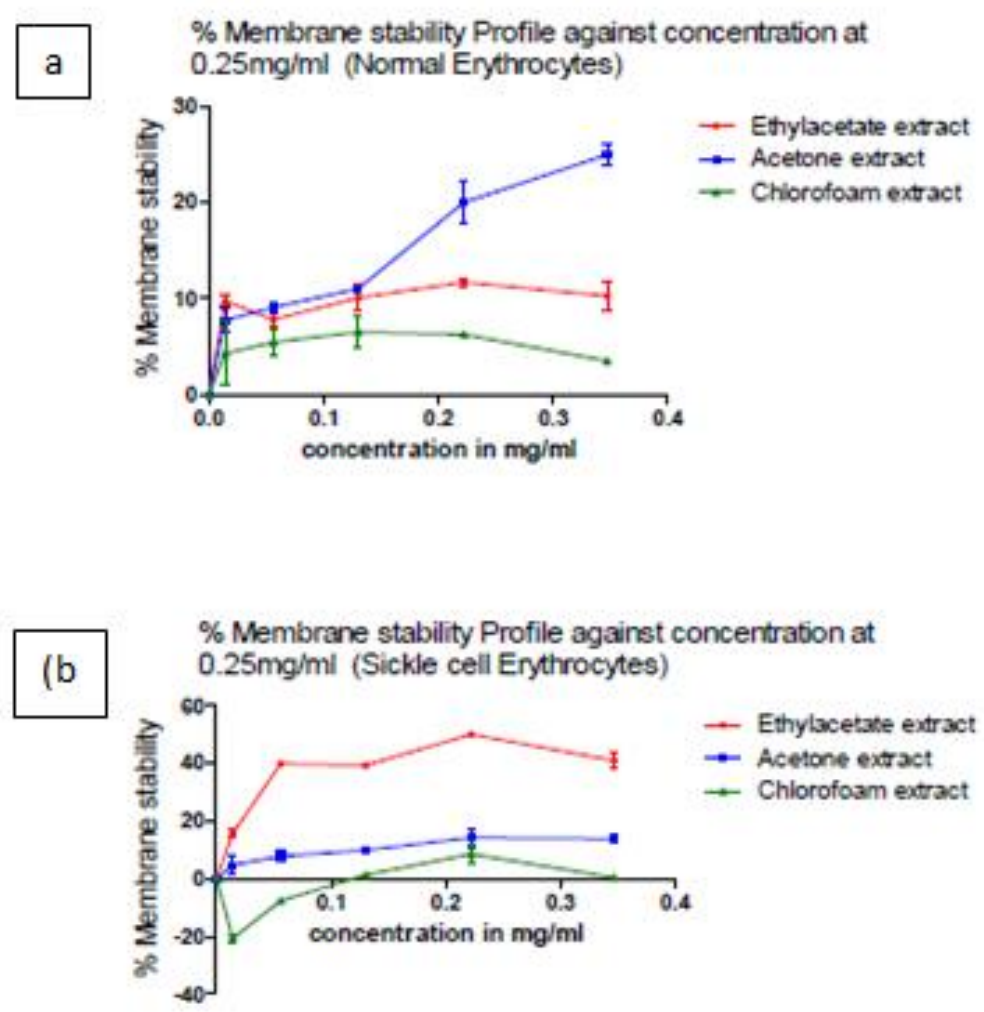

Fig. 1(a, b): Membrane stabilizing profiles of ethylacetate, acetone and chloroform extracts of A. ohioense on normal (a) and sickle (b) erythrocytes at $0.25 \mathrm{mg} / \mathrm{ml}$. Each value represented the mean $\pm \mathrm{SEM}$ of readings 

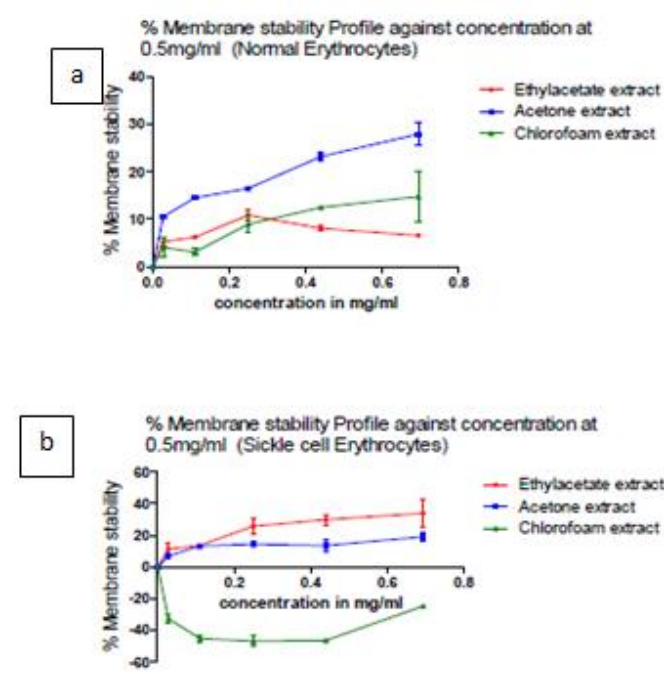

Fig. 2 (a, b): Membrane stabilizing profiles of ethylacetate, acetone and chloroform extracts of A. ohioense on normal (a) and sickle (b) erythrocytes at $0.5 \mathrm{mg} / \mathrm{ml}$. Each value represented the mean $\pm \mathrm{SEM}$ of readings
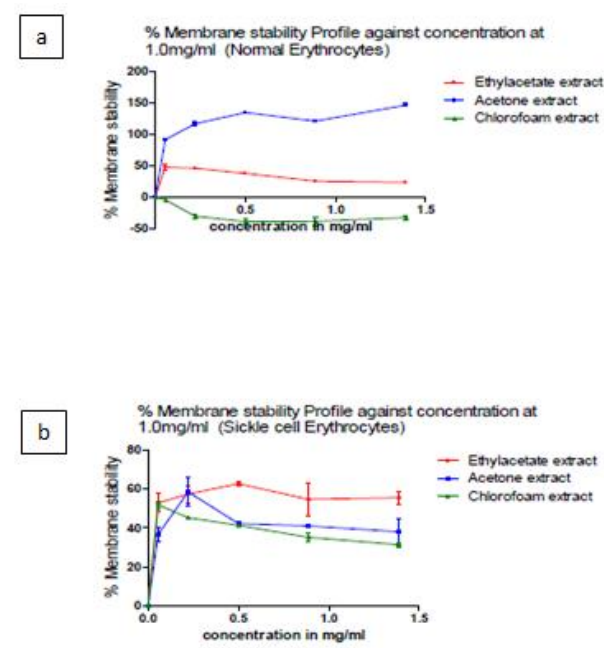

Fig. 3(a, b): Membrane stabilizing profiles of ethylacetate, acetone and chloroform extracts of A. ohioense on normal (a) and sickle(b) erythrocytes at $1.0 \mathrm{mg} / \mathrm{ml}$. Each value represented the mean $\pm \mathrm{SEM}$ of readings
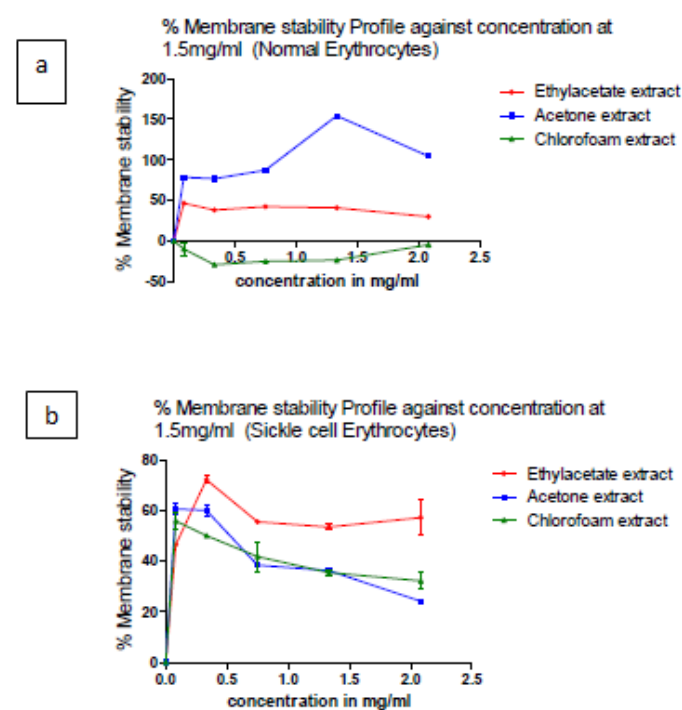

Fig. 4(a, b): Membrane stabilizing profiles of ethylacetate, acetone and chloroform extracts of A. ohioense on normal (a) and sickle (b) erythrocytes at $1.5 \mathrm{mg} / \mathrm{ml}$. Each value represented the mean \pm SEM of readings 

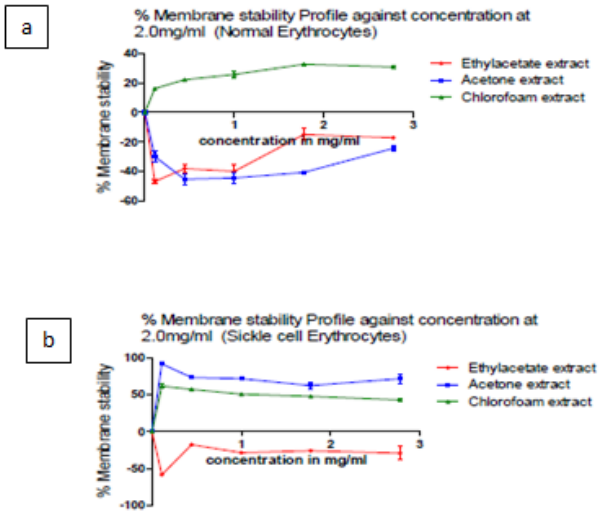

Fig. 5(a, b): Membrane stabilizing profiles of ethylacetate, acetone and chloroform extracts of A. ohioense on normal (a) and sickle(b) erythrocytes at $2.0 \mathrm{mg} / \mathrm{ml}$. Each value represented the mean $\pm \mathrm{SEM}$ of readings
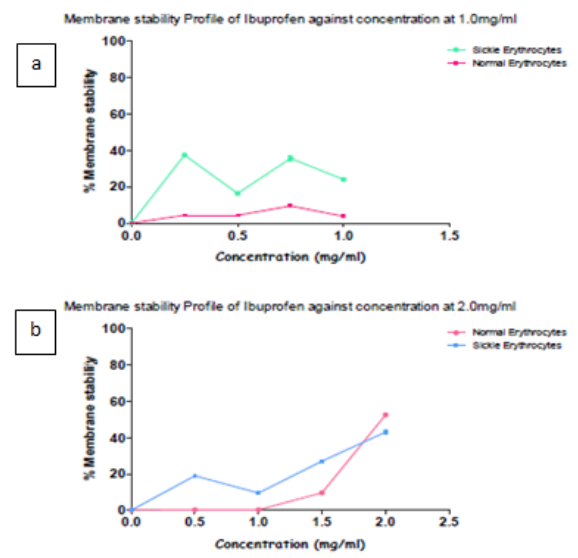

Fig. 6 (a, b): Membrane stabilizing Ibuprofenon normal and sickle erythrocytes at $1.0 \mathrm{mg} / \mathrm{ml}$ (a) and $2 \mathrm{mg} / \mathrm{ml}$

(b). Each valuerepresented the mean \pm SEM of readings

Table 2:Lipooxygenase and Xanthine Oxidase Inhibitory Activities of Chloroform,Acetone and Ethylacetate of

\begin{tabular}{|l|l|l|}
\multicolumn{3}{|c|}{ A. ohioense. } \\
\hline & $\begin{array}{l}\text { Lipoxygenase Activity } \\
\mathrm{U} / \mathrm{ml}\end{array}$ & $\begin{array}{l}\text { Xanthine oxidase activity } \\
\mathrm{U} / \mathrm{ml}\end{array}$ \\
\hline Chloroform extract & $2.7 \times 10^{-3} \pm 0.005$ & $1.08 \times 10^{-3} \pm 0.0004$ \\
\hline Acetone extract & $3.6 \times 10^{-3} \pm 0.001$ & $3.6 \times 10^{-2} \pm 0.008$ \\
\hline Ethylacetate extract & $2.0 \times 10^{-3} \pm 0.002$ & $2.4 \times 10^{-2} \pm 0.0000$ \\
\hline Quercetin & $7.2 \times 10^{-3} \pm 0.001$ & $\mathrm{ND}$ \\
\hline
\end{tabular}

The values represent the means of triplicate absorbance + SEM

ND - Not determined

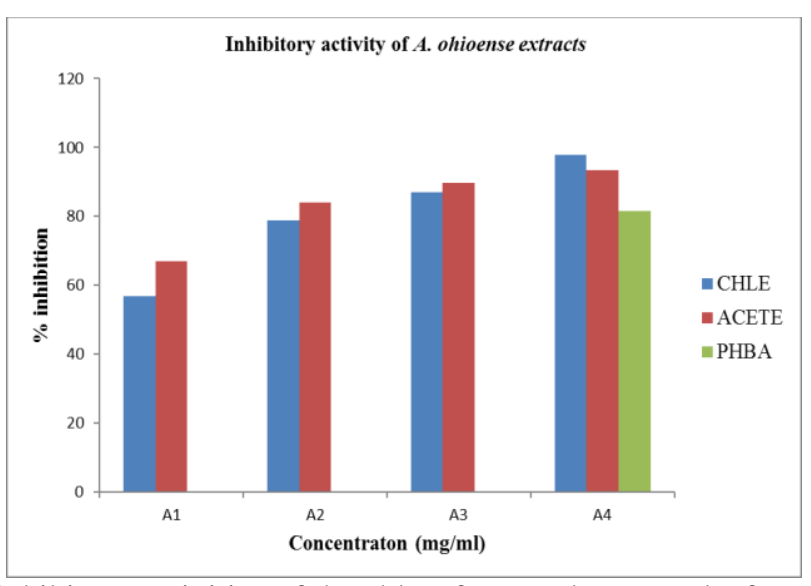

Fig.7:The relative inhibitory activities of the chloroform and acetone leaf extracts of $A$ ohioense 
Keys: $\quad$ CHLE $=$ Chloroform Extract, $\mathrm{ACETE}=$ Acetone Extract

$\mathrm{A} 1=0.5 \mathrm{mg} / \mathrm{ml}, \mathrm{A} 2=1.0 \mathrm{mg} / \mathrm{ml}, \mathrm{A} 3=2.0 \mathrm{mg} / \mathrm{ml}, \mathrm{A} 4=4.0 \mathrm{mg} / \mathrm{ml}$ and PHBA (Positive control) = Parahydroxybenzoic acid, Data are expressed as $\pm \mathrm{SEM}(\mathrm{n}=3)$ for each group. All of them are significant at $\mathrm{p} \leq$ 0.0001 degree.

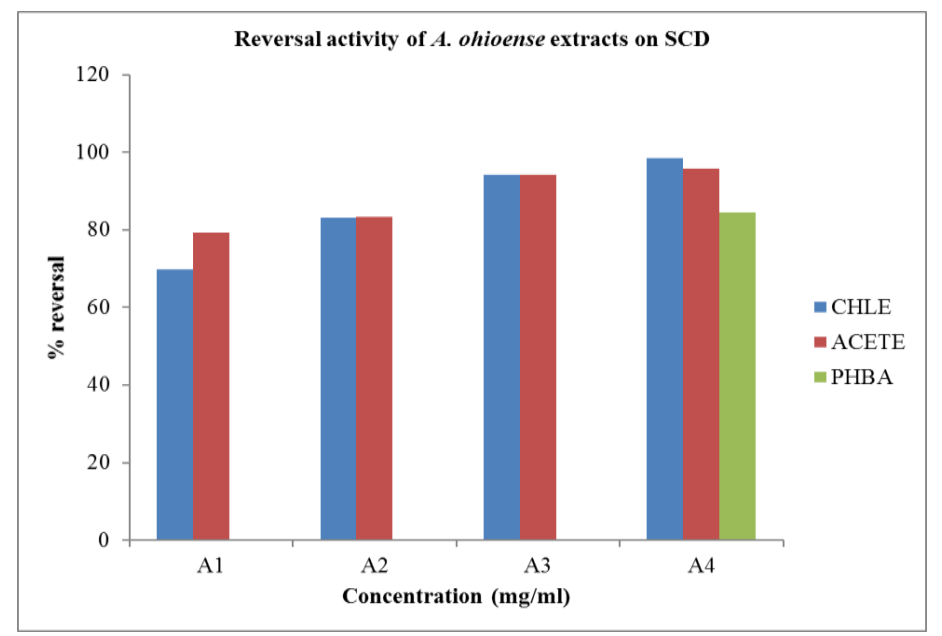

Fig. 8:The relative reversal activities of the chloroform and acetone leaf extracts of $A$ ohioense

Keys: $\quad$ CHLE $=$ Chloroform Extract, $\mathrm{ACETE}=$ Acetone Extract

$\mathrm{A} 1=0.5 \mathrm{mg} / \mathrm{ml}, \mathrm{A} 2=1.0 \mathrm{mg} / \mathrm{ml}, \mathrm{A} 3=2.0 \mathrm{mg} / \mathrm{ml}, \mathrm{A} 4=4.0 \mathrm{mg} / \mathrm{ml}$ and PHBA (Positive control) $=$ Para-

hydroxybenzoic acid. Data are expressed as $\pm \operatorname{SEM}(\mathrm{n}=3)$ for each group. All of them are significant at $\mathrm{p} \leq$ 0.0001 degree

\section{Discussion}

Phytochemical screening of the extracts (ethylacetate, acetone and chloroform) of A. ohioensegave a positive test for the presence of alkaloids, cardiac glycoside, flavonoids, phlobatanin, saponins, steroid, tannin and triterpene. These phytoconstituents have been demonstrated to possess a wide range of activities. Tannins are astringent polyphenols, though considered as anti-nutritional due to its decrease in the digestibility of proteins, it had been employed as antidiarrheal, hemostatic, and anti-hemorrhoidal compounds [20]. Saponins have various biological activities such as the expectorant, diuretic and adaptogenic activities associated with them. They are also responsible for the characteristic bitter taste of most plants [21, 22]. Flavonoids and phenolic compounds have been reported to exert multiple biological effects which include antioxidant, free radical scavenging abilities, anti-inflammatory, anti-carcinogenicetc.[23]. The biological importance of cardiac glycosides primarily is in the treatment of cardiac failure. They result in an increase in cardiac output by increasing the force of contraction as a result of their ability to increase intracellular calcium concentrations [24]. Thus, the presence of these phytochemicals might be responsible for the reported anti-inflammatory and antisickling activities of the plant.

Plants derived drugs have been reported to promote stability of biological membranes when stressed [25]. Several investigations have backed up the possibilities that stability of various humanerythrocytes (HbAA,HbAS andHbSS) membranes varied [26 - 28].

Figs. 1-6 showed the membrane stabilizing profiles of human normal and sickle erythrocytes exhibited by $A$. ohioense extracts at different concentrations $(0.25 \mathrm{mg} / \mathrm{ml}$ to $2.0 \mathrm{mg} / \mathrm{ml})$ and Ibuprofen $(1.0 \mathrm{mg} / \mathrm{ml}$ and $2.0 \mathrm{mg} / \mathrm{ml})$ on red blood cells exposed to heat and hypotonic induced lyses.

At $0.25 \mathrm{mg} / \mathrm{ml}$, it was observed that all the extracts protected normal erythrocytes (Fig.1a). Acetone extract showed monophasic mode of protection while the remaining two extracts protected better at lower concentrations. On sickle erythrocytes (Fig.1b), ethyl acetate and acetone extracts protected better while chloroform extract stabilizedthe red blood cells slightly. At $0.25 \mathrm{mg} / \mathrm{ml}$ acetone extract protected normal erythrocytes better whileethylacetate extract stabilizedthe sickled erythrocytes better.

On normal erythrocyte at $0.5 \mathrm{mg} / \mathrm{ml}$ (Fig. 2a), as the mode of protection increased as the acetone and chloroform extracts concentration increases extracts and ethyl acetate mode of protection decreases. In Fig. 2b, of the three extracts, only ethylacetate and acetone extracts protected sickle erythrocytes. At this concentration, just as in $0.25 \mathrm{mg} / \mathrm{ml}$ ethylacetate extract protected sickle erythrocytes better than normal erythrocytes.

In Fig.3a, it was observed that ethylacetate and acetone extracts protected normal erythrocyte better at low concentration in biphasic manner at $1.0 \mathrm{mg} / \mathrm{ml}$. All the three extractswereobserved to protect sickle erythrocytes 
effectively at lower concentrations (Fig.3b).The extracts protected both normal and sickled erythrocytes against heat and induced lyses and compared favourably with Ibuprofen at $1 \mathrm{mg} / \mathrm{ml}$ (Fig.6a).

The membrane stabilizing profiles of normal and sickled erythrocytes at $1.5 \mathrm{mg} / \mathrm{mlwere}$ as shown in Fig. $4 \mathrm{a}$ and b. Acetone extractwas observed to exhibits highest mode of protection on normal erythrocytes (Fig.4a) and ethyl acetate extract on sickle cell erythrocytes (Fig.4b). Chloroform extractwas observed not to protect normal erythrocyte at $1.5 \mathrm{mg} / \mathrm{ml}$ (Fig.4a)

At $2.0 \mathrm{mg} / \mathrm{ml}$, only chloroform extract stabilizes normal erythrocytes (Fig.5a) while acetone and chloroform extracts protected sickle erythrocytes (Fig.5b). The extracts that protected at $2 \mathrm{mg} / \mathrm{ml}$ compared favourable with a standard anti-inflammatory drug ibuprofen (Fig. 6). It could be surmised that ethyl acetate extract the was toxic to erythrocytes membrane at higher concentration.

The membrane stabilizing profile (Figs. 1 - 6)revealed that acetone and ethyl acetate extracts of A. ohioense protected red blood cell membrane at various concentration except at $2.0 \mathrm{mg} / \mathrm{ml}$. However, the chloroform extract of the plant exhibits a profound protective effect on both normal and sickle l erythrocytes only at higher concentration.

Lipoxygenase and xanthine oxidase are key enzymes implicated in many mediated inflammation diseases such as cancer, arthrosclerosis, hypertension and diabetes [29]. Their inhibition could be a way for finding new anti-inflammatory agent/ compound.Table 2 shows the summary of lipoxygenase and xanthine oxidase inhibitory activities of chloroform, acetone and ethylacetate of A. ohioense. All the extracts showed low inhibitory activities compared to Quercetin.

Furthermore, A ohioense chloroform and acetone extracts exhibitedappreciable anti-sickling activities. There is linear increase in the inhibitory activity of the two extracts with higher inhibitory activity in chloroform extract having $97.75 \%$ while acetone extract has inhibitory potential of $93.51 \%$ (Fig.7). This compared favorably with positive control Para-hydroxybenzoic acidwith percentage inhibitory activity of 81.50 . Also, as shown in Fig.8, A. ohioense chloroform and acetone extractsdemonstrated significant $(\mathrm{P}<0.001)$ increased in antisickling reversal activity as the concentrations of the extracts increases.

Some medicinal plants such as Piper guineensis, Pterocarpus osun, Eugenia caryophyllala and Sorghum bicolor extracts had been reportedin the treatment of sickle cell disorder[30]. Also, the extracts of Pterocarpus and Aloe vera were also reported to increase the gelling time of sickle cell blood and inhibits sickling in vitro[31].This study indicates the potential of A. ohioense extract in the management of sickle cell disorder.

\section{Conclusion}

The result of this study suggested that A. ohioense possess anti-inflammatory and antisickling activities. Therefore $A$. ohioense could be regarded as a potential anti-inflammatory plant that can play essential role in the management and treatment of sickle cell disorder and offer stability to the membrane of already reversed Hbs molecules. However, the need to carefully investigate the plant toxicity, isolate compound(s) responsible for the observed anti-inflammatory effect and develop suitable formulation beneficial for antiinflammatory related disorder is thereby suggested.

\section{References}

[1]. Steinberg, M.H. (2008) Sickle cell anemia, the first molecular disease: Overview of molecular etiology, patho- physiology, and therapeutic approaches. The Scientific World Journal, 8, 1295-1324.

[2]. Martins, D.W. (1981). Porphyrins and bile pigments. Harper's Review of Biochemistry, 212-214

[3]. Karayakin, H.N. (1979). Cholelithiasis in children with sickle celldisease. American Journal Dis Child 133:306-307.

[4]. Steinberg, M.H. (2005) Predicting clinical severity in sickle cell anaemia. British Journal of Haematology129: 465-481.

[5]. Diabetes Research 2015. Complications and TreatmentsSickle cell disease. Http://www.cailsilorin.com.

[6]. Chikezie, P.C. (2006). Studies on the anti-sickling effects of Azadirachta indica and Vernonia amygdalina on HbSS erythrocytes. Inter. J. Nat. Appl. Sci.2:24-8.

[7]. Chikezie, P.C. (2007). Effect of ethanolic extracts of Garcina kola, Cola nitida and Cola acuminata on in vitro haemoglobin S polymerization.Inter. J. Trop. Agric. Food Sys.;1:220-5.

[8]. Ekeke, G.I. and Shode, F.O. (1985). The reversion of sickled cells by Cajanus cajan. Planta Medica 6:504-7.

[9]. Okpuzor, J., Adebesin, O., Ogbunugafor, H. and Amadi, I. (2008). The potential of medicinal plants in sickle cell disease control: A review. Inter. J. Biomed. Health Sci.4:47-55.

[10]. Flora of North America (2008). Missouri Botanical Garden 27:315-318

[11]. Akinpelu, B.A., Makinde, A.M., Isa, M.O., Taiwo, O.P., Ojelabi, O.M. and Oyedapo, O.O. (2015). In vitro Evaluation of Membrane Stabilizing Potential of Selected Bryophyte Species. European Journal of Medicinal Plants6 (3): $181-190$.

[12]. Evans, W.C. (2002). Phenols and Phenolic glycosides. In Trease andEvans Pharmacognosy, Elsevier Science Limited, pp. $214-252$.

[13]. Sofowora, A. (2006). Phytochemical screening: In "Medicinal plants and TraditionalMedicine in Africa", Second Edition, Spectrum BooksLimited Ibadan, Nig., pp. 150-153.

[14]. Oyedapo, O.O., Akinpelu, B.A., Akinwunmi, K.F., Adeyinka, M.O., Sipeolu, F.O. 2010Red blood cell membrane stabilizing potentials ofextract of Lantana camara and itsfractions. Int. J. Plant Phy. and Biochem.2(4);46-51.

[15]. Oyedapo, O.O., Akinpelu, B.A., Orefuwa, S.O. (2004). Anti-inflammatoryeffects of Theobroma cacao, L. root extract. J.Tropical med. Plants(Malaysia) 592): 161-166.

[16]. Malterud, K.E and Rydland, K.M. (2000). Inhibitors of 15 -lipoxygenase from orange peel. Journal of Agriculture and Food Chemistry 48, $5576-5580$. 
[17]. Ferraz Filha, Z.S., Vitolo, I.F., Fietto, L.G.,Lombardi, J.A. and Saude-Guimares, D.A. (2006). Santhine oxidase Inhibitory activity ofLychnophora species from Brazil(“Arnica). Journal of Ethnopharmacology 107, 79 - 82.

[18]. Egunyomi, A.J., Moody, O. and Eletu,O. (2009). Antisickling activities of two ethnomedicinal plant recipes used for the management of sickle cell anaemia Ibadan, Nigeria, African Journal of Biotechnology Vol. 8 (1), pp. 020-025.

[19]. Sofowora, E.A., Isaac-Sodeye, W.A., Ogunkoya, L.O. (1979). Isolation and Characterization of an antisickling agent from the root of Fagaraxanthoxyloides. African Medicinal Plants. Proceedings of a Conference Ed. Sofowora EA, pp. 89-97.

[20]. Lamy, E., Graça, G., da Costa, G., Franco, C.E., Silva, F.C., Baptista, E.S. and Coelho, A.V. (2010). Changes in mouse whole saliva soluble proteome induced by tannin-enriched diet. Proteome Science 8(65): 1-12.

[21]. Kensil, C.R. (1996). Saponins as vaccine adjuvants. Critical Reviews in Therapeutic DrugCarrier Systems 13: 1-55.

[22]. Barr, I.G., Sjolander, A. and Cox, J.C. (1998). ISCOMs and other saponin based adjuvants (Review). Advanced Drug Delivery Reviews 32: 247-271.

[23]. Lalitha, T. P. and Jayanthi, P. (2012). Asian journal of. Plant Science Res., 2(2), 115-122.

[24]. Xie, Z. and Askari, A. (2002). Na+/K+-ATPase as a signal tranducer. European Journal ofBiochemistry 269 (10): 2434-2439.

[25]. Sadique J., Al-Rqobahi W.A., Bughaith M. F. and El-Gindy A. R. (1989). The bio-activity of certain medicinal plants on the stabilization of RBC membrane system. Fitoterapia 60 (6), 525-532.

[26]. Onah J. O, Akubue P. I, and Okide J. F. (2002). The kinetics of reversal of pre-sickled erythrocytes by the aqueous extract of Cajanus cajan; Phytother. Res. 16(8): 748-750

[27]. Elekwa I, Monanu M. O and Anosike E. O (2003) Studies on the effect of aqueous extracts of Garcinia kola seed on the human erythrocytes adenosine triphosphatase of HbAA, HbAS, and HbSS genotypes. Global J. Med Sci. 2(2). 107-114.

[28]. Okpuzor J, Adebesin O. Membrane stabilizing effect and antisickling activity of Senna podocarpa and Senna alata. $31^{\text {st }}$ congress for European biochemical societies, Instanbul, Turkey, July 25-29, 2006.

[29]. Osher, E., Weisinger, G., Limor, R., Tordjman,K. and Stern, N. (2006). The 5-lipoxygenase system in the vasculature: Emerging rolein health and disease. Molecular and Cellular endocrinology $252: 201-206$. Molecular and Cellular Endocrinology .

[30]. Wambebe C, Khamof,. H and Momoh J. A. (2001). Double-blind, placebo-controlled, randomised cross-over clinical trial of NIPRISAN in patients with sickle cell disorder Phytomedicine8(4):252-61.

[31]. Ugbor, C. (2001). The effect of vegetable extracts on the antisickling potential of Aloe vera. 2006 www.biochemistry.org/meetings/abstracts/BS2006/BS20060567.pdf. 